\title{
Mapping Of Learning Achievement And Profile Of Graduates Of Bachelor Of Education Technology In Several Universities In Indonesia As An Effort To Strengthen Development Profession Of Competitive Instuctional Technology
}

\author{
Agus Wedia, Ence Surahmana \\ ${ }^{a}$ State University of Malang, Malang, Indonesia \\ Corresponding e-mail: agus.wedi.fip@um.ac.id
}

\begin{abstract}
The diversity of learning achievements and the profile of graduates of educational technology programs in Indonesia has become an obstacle to the common interest in the existence and development of professions and science of Education Technology in Indonesia. The study in this paper reveals the mapping of learning achievements and the profile of educational technology graduates in several universities in Indonesia. From learning achievement mapping and graduate graduate profile, it is clear that the learning achievement has not been standardized all the Education Technology program. In addition, the core courses of educational technology can be developed in accordance with KKNI standards and basic task of functional position of technology learning developers. These are some perceptions about the profile of graduates of educational technology courses that can be referred to by stakholder not only for the internal educational technology community but for the external side of the educational technology community. The follow up of this descriptive analysis is the possibility to approve the number of core courses on a national scale as initiated through the Association of Indonesian Education Technology Studies Programs. It intends to prepare the technological workforce of reliable learning and open more space for the graduation of educational technology in order to improve the quality of education of Indonesia.
\end{abstract}

Keywords: competence, educational technology, profession

\section{INTRODUCTION}

Education Technology Profession (TP) in Indonesia has been developed in the last few decades. This is in line with the opening of educational technology degree programs in several educational institutions and educational personnel (LPTK) such as the University of Malang (UM), University of Education Indonesia (UPI), State University of Jakarta (UNJ) and several other campuses ex IKIP. After several years of graduation and several graduates of TP program entered government institutions as civil servants/ASN finally Functional Position and Credit Score out through the Regulation of State Minister of State Apparatus Empowerment Number:PER/2/M.PAN/ 3/2009 concerning Functional Position and Credit Score. The regulation provides good news for TP graduates. On the other hand, however, the regulation raises its own challenges for TP program developers to align the developed curriculum with the main tasks set forth in the regulation. This is due to the diversity in curriculum development of existing TP program.
In the last two years the Association of Indonesian Education Technology Studies Program (APS-TPI) gathered to discuss the Achievement of Learning of Graduates of TP study program. It is intended that all TP Studies Programs incorporated in APS-TPI align the curriculum developed in order to meet the standards set forth in the Indonesian National Qualification Framework (KKNI) and the main tasks and functions (TUPOKSI) contained in the Regulation of the State Minister for the Empowerment of the State Apparatus Number :PER/2/M.PAN/3/2009 on Functional Position and Credit Score.

This paper aims to analyze the differences in the profile and competence of graduates of TP study program in several universities in Indonesia namely in UM, UPI, UNJ, and UNDIKSHA. Differences in the profile and competence of each graduate are linked to the curriculum standards of the 2012 Association for Educational Communications and Technology (AECT), KKNI and the TUPOKSI developers of Learning Technology/Education as stipulated in the Regulation of the State Minister for the Empowerment of State Apparatus 


\begin{abstract}
Number:PER/2/M.PAN/3/2009 on Functional
Position and Credit Score.

This paper is written using literature analysis and comparative analysis on the profile and competence of TP graduates in some Indonesian universities. The results of the analysis are presented descriptively. The benefits of writing in this paper are expected TP developers in Indonesia can harmonize the standard curriculum with AECT 2012 standard, KKNI and Tupoksi in Functional Education Technology. Other benefits of TP TP graduate stakeholders can develop professional lands for TP graduates.
\end{abstract}

\section{DISCUSSION}

Discussion of the contents of this paper contains a description of: 1) general profile profiles of TP UM (Malang), UPI (Bandung), (Jakarta) UNJ, and UNDIKSHA (Bali) include the elaboration of objectives, achievement of graduate learning/competence, and graduate profile, additional areas of expertise/concentration, uniform courses, Which is typical in the TP S1 Study Program in several universities in Indonesia; 2) Review of TP expertise with KKNI standards; 3) A review of the functional skills of the technological developer technology developer; 4) Links between learning achievements, graduate profile, standard KKNI skills demands and expertise in functional positions of learning technology developers, and 5) typical subjects of each TP S1 program in some campuses in Indonesia.

\subsection{General profile of TP Prodi at UM, UPI, UNJ (Jakarta), and UNDIKSHA (Bali)}

Based on information obtained from lecturers and onformation networks available on UM, UPI, UNJ and UNDIKSHA study websites, including information on general profile (learning achievement/graduates/goals competency and field of expertise/concentration and graduate profile) of S1 TP UM, UPI, UNJ, and UNDIKSHA.

\subsubsection{Prodi S1 TP FIP UM}

The purpose of the Department of Education Technology FIP State University of Malang include; 1) produce educational/learning technology developers capable of designing, developing, utilizing, and managing and evaluating education, learning and training programs, processes and products in various pathways, types and levels of education; 2) producing educational staff as developers Educational unit curriculum, education and training, and library management; 3 ) produce academic work through research and development activities in the field of education/learning technology, and 4) empower the community through the application of various educational technology/learning.

The profile of graduates/Achievement of Study Program S1 TP UM among others are; 10 Faithful and devoted to God Almighty; 2) Having a superior personality in accordance with the basic philosophy of the Pancasila state and the 1945 Constitution and has high integrity in the life of the nation and state; 3) Mastering the theory and practice in the field of educational/learning technology; 4) Be able to design, develop, utilize, manage, and assess programs, processes, and educational and learning products; 5) Ability to research and use research results in the field of educational and learning technology; 6) Ability to design, develop, memprottion, utilize, manage, and assess media and learning resources; 7) Able to develop and manage the education and training curriculum; 8) Able to develop and manage learning resources and libraries in various lines, types, and levels of education; 9) Able to disseminate the results of technological innovation education/ learning.

Prodi S1 TEP UM has additional areas of expertise in addition to the core TP science field. Additional expertise in question is 1) Information and Communication Technology (ICT) that is mandatory for all students and additional expertise of choice that is 2) Curriculum and 3) Education and Training.

The total number of credits in S1 Study Program of S1 UM as many as 143 SKS, with the details of personality development courses of 8 credits, 8 credits of science education, science subject and skill I 10 credits, scientific subjects and skill II 38 credits, Working 35 credits, selected courses on ICT 13 skills, 12 curriculum, education and training 12 , 10 work attitude courses, 9 community lectures, and 4 additional courses of credits.

\subsubsection{Prodi S1 TP FIP UPI}

Graduates of Bachelor Degree (S1) Undergraduate Technology Study Program are expected to be able to achieve competence in accordance with KKNI level 6 with the following capabilities: 1) Have the ability and ability to make the right decision and professional based on the analysis result of information and data, and can choose various Alternative solutions independently and in groups to solve learning problems and 
developmental services of learners who face it in accordance with the context to obtain the best learning outcomes and the development of optimal learners; 2) Mastering theoretical and practical knowledge in designing, developing, managing and assessing educational programs/processes and products/learning in performing tasks as educational technologists/education in various channels, types, and levels and forms of education; 3) Able to research and use research results in Curriculum Development, Education/Learning, and Library and Information Technology; 4) Mastering theoretical and practical knowledge in designing, implementing, presenting and disseminating research in the field of science of education/learning technology, curriculum and ICT; 5) Mastering theoretical and practical knowledge in conducting learning as teachers, instructors, facilitators, tutors, widyaiswara, \& trainers in the field of curriculum, learning and ICT scholarship.

The next graduate competency 6) Designing, developing, managing and assessing the program, process and product education/pembelajaran in carrying out duties as a technologist education/learning in the various channels, types, and levels and forms of education; 7) Designing, developing, managing, and assessing the curriculum in the implementation of tasks for engineering curriculum in the various channels, types, and levels and forms of education; 8) Conduct learning as teachers, instructors, facilitators, tutors, lecturers, and trainers in the field of science curriculum, learning and ICT; 9) Demonstrate the integrity and stability of a strong personality and display quality performance; 10) Have ethics, aesthetics, attitudes appreciative, participatory, creative, innovative, and productive and responsible in carrying out duties as a technologist education/learning, engineer curriculum, researchers, and educators (teachers, instructors, facilitators, tutors, lecturers, and trainers) In the field of scientific education/learning technology, curriculum and ICT. The keminatan program that can be chosen by the students which curriculum developers and keminatan keminatan Information and Communication Technology (ICT) (kurtek.fip.upi.edu).

The total number of SKS of S1 UPI Prodi S1 students is 147 SKS with 14 credits General Course, 12 Basic SKS Courses, 4 SKS Field Experiences Courses, 6 SKS Faculty Skills Courses, Professional Skills Courses 11 SKS , 84 SKS study subjects, and in-depth and extension courses of 16 credits.

\subsubsection{Prodi S1 TP FIP UNJ}

Based on the information contained in the draft of curriculum book of Education Technology Program of FIP UNJ, obtained information about the purpose of Prodi S1 TP UNJ among others; 1) Have the ability to design, implement, and process and report research results in the field of learning and learning, both conventional, innovative, and resource-based technology; 2) Having the ability to disseminate research results through scientific communication media; 3) Have the ability to solve learning and learning problems ranging from conventional, innovative and resource-based technology; 4) Have the ability to disseminate / socialize the findings and modifications of conventional learning and learning solutions up to technology-based sources; 5) Generate creative graduates of entrepreneurship, independent, open to changes and differences through interaction in lectures and structured tasks; 6) Increasing the potential of students through their involvement in various lecturers' research and lectures and community service programs; 7) Increasing the potential of students through the involvement of lecturers in the activities of student organizations, academics and institutions; 8) Produce graduates who uphold professional ethics through the guidance of lecturers in writing thesis and other papers; 9) To produce graduates who uphold professional ethics through the guidance of lecturers in organizing seminars and writing scientific papers; 10) Produce graduates who uphold professional ethics through lecturers' guidance in academic interaction; 11) Produce graduates who uphold professional ethics through the guidance of lecturers to appreciate intellectual property rights.

Profile of graduate of Prodi S1 TP UNJ divided into two that is developer of learning technology and developer of performance technology. What is meant by the graduate profile as a developer of learning technology, among others, prepares graduates to become learning designers/trainers, helps curriculum development in various education units (schools and non-schools), manages the resources (and media) learning and ICT utilization for learning/training. This concentration also fosters competence that refers to the ability to develop media and / or learning resources, from conventional to the use of ICT for an educational institution independently. While the description of the graduate technology developers performance profile that is concentrating to develop the competence that refers to the needs of the organization to improve the quality of human resources performance through various learning and learning/training and the 
implementation of ICT (organization-oriented). Such competencies include developing training models and curricula, learning/training interventions, media utilization for training, training needs analysis, as well as evaluation and assessment for training (Curriculum of TP UNJ Programs).

Achievement of graduate of $\mathrm{S} 1$ program of newest UNJ has follow the standard of learning achievement agreed by APS-TPI that is learning achievement based on KKNI. In the elucidation of learning achievement is divided into aspects of attitude, general skills, special skills and knowledge.

The total number of SKS in the subjects of study program S1 of UNJ is 155 credits, with details of 13 credits of general subjects, 12 credits of basic courses of education, subjects of courses consisting of subjects of expertise and support of 121 credits, and courses of learning as much 8 credits. Total number of credits Prodi TP UNJ is the most when compared with the number of SKS other TP prodi.

\subsubsection{Prodi S1 TP FIP UNDIKSHA}

Information obtained by the author on the general profile of Prodi S1 TP UNDIKSHA contains the expected graduates profile as 1) Developers of Learning Technology; 2) Educators of Information and Communication Technology (ICT); 3) Journalist and 4) Entrepreneur in the Field of Education and Training. The additional areas of expertise / konsetrasi that can be selected by students include; 1) Education Information and Communication Technology; And 2) Journalism.

The total number of SKS in the subjects of Study Program S1 TP UNDIKSHA as much as 150 credits, with the details of general courses 14 credits, scientific subjects and skills 22 credits, subjects of 97 SKS, 5 community lectures SKS, 12 credits of educational communication, and 12 credits journalistic skills courses.

\subsection{The 'uniform' courses in all S1 courses of UM, UPI, UNJ, and UNDIKSHA}

Define abbreviations and acronyms the first time they are used in the text, even after they have been defined in the abstract. Abbreviations such as IEEE, SI, MKS, CGS, sc, dc, and rms do not have to be defined. Do not use abbreviations in the title or heads unless they are unavoidable.

Based on the information contained in the curriculum structure of S1 Study Program UM, UPI, UNJ, and UNDIKSHA can be traced several core courses of the same TP study program. Some of the courses in question include; 1) Educational technology; 2) Education technology profession; 3) Planning/Design/Design learning; 4) Message design; 5) Development of teaching materials; 6) Learning center resource management; 7) Learning strategy; 8) Learning model; 8) Learning media; 9) Graphical media; 10) Photo media (photography); 11) Audio / radio media; 11) Visual media; 12) 3 dimensional media; 13) curriculum development; 14) Evaluation of learning; 15) Evaluate the curriculum; 16) Design of training programs; 17) Management training; 18) Evaluation of training programs; 19) Educational communication; 20) Computer basics; 21) Computer based learning; 22) Electronic learning (e-learning); 23) Online learning (online learning); 24) Diffusion of educational technology innovation; 25) Human Resource Development; 26) Research and development of TP field.

In general, based on the author's analysis, several uniform courses and taught in all study programs have been aligned with the competence demands set forth in the PTP Functional Position. In more detail the explanation of the main task of PTP Functional Position is described in the next discussion.

\subsection{Main Tasks of Functional Positions of Learning Technology Developers}

The position of Developer of Learning Technology is a position that has scope, duty, responsibility, and authority to carry out the development of learning technology occupied by civil servants with rights and obligations given fully by authorized officials (Permenpan no 2 2019; I Article 1 verse1). Development of learning technology is a process of analysis, assessment, design, production, application and evaluation of learning technology system/model (Chapter I Article 1 Paragraph 2). Learning Technology is a field that 
systematically integrates learning resource components that include: people, teaching content, media or teaching materials, tools, 24 techniques, and environments, used to educate learners on all paths, levels and types of education (Chapter I Article 1 Paragraph 3).

The main task of developers of learning technology in accordance with the standard Permenpan No. 2 of 2009 are: 1) Analysis and assessment of learning technology model/system; 2) System design/model of learning technology, 3) Production of instructional media, 4) application of system/model and utilization of instructional media, 5) Control system/learning model and 6) evaluation of system/model implementation and utilization of instructional media.

Details of the main functional tasks of the PTP are adjusted to the level of their position (Oka, 2012). For example the details of the first basic task of the developer are as follows: 1) Analyze system requirements and learning technology model of difficulty level 1 based on curriculum applicable according to type, path and level of education; 2) Making system design / learning model, difficulty level 1; 3) Make learning service standard, difficulty level 1; 4) Prepare the Media Content Outline (GBIM), difficulty level 1; 5) Making the design of learning materials of difficulty level 1 ;6) Write a simple instructional media script; 7) Writing audio learning media scripts; 8) Write a video instructional video script; 9) Writing text of multimedia learning media; 10) Writing text of interactive multimedia learning media / hypermedia; 11) Writing instructional media learning materials self-learning (module); 12) Testing prototypes of simple learning media; 13) Conducting a prototype trial of audio learning media; 14) Testing prototype of video learning media; 15) Testing prototypes of multimedia learning media; 16) Testing prototype interactive multimedia learning media/hypermedia; 17) Conducting a prototype trial of learning media self-learning materials (modules); 18) Writing text of accompanying materials of audio learning media; 19) Writing text of accompanying material of video learning media; 20) Writing text of accompanying material multimedia learning media; 28 21) Writing text of accompanying materials of interactive multimedia learning media/hypermedia; And 22) Providing consulting services in the application of system/model development and utilization of learning media level of difficulty. (Permenpan No: PER/2/M-PAN/2009;09).

The details of the main tasks at the junior and senior level positions differ only in the level of competence demands, for the younger level the PTP is required to be a member and the middle level is required to be the chairman of the project designing, developing, utilizing, managing and evaluating the learning system /model.

Based on the details of the main tasks at each level of the position, can be drawn several key competencies including the following competencies; 1) competence analysis system/model needs both in learning and training. Requirements analysis includes all components in it such as analysis of overall learning system needs, program needs analysis, needs analysis strategy, methods, media, and program evaluation. 2) the design competencies of all components of the learning system, and the training, both in the components of the design of learning, design, media (audio, video, graphics, 2D, $3 \mathrm{D}$, multimedia and hypermedia), the design of teaching materials, the design of the learning environment, and the evaluation design. 3) competence development of all components in learning that includes the development of teaching materials, learning media, props, and others. 4) competence to implement or apply the design result to all learning components, including application of media, model, strategy, learning materials, learning environment background, including implementation of evaluation process. 5) competence of evaluation of all learning components, including evaluation on needs analysis process, then evaluation of learning design, evaluation of learning implementation, and evaluation of learning process evaluation itself. Thus the details of the main tasks of the functional position of PTP in accordance with the five areas of science TP that is design, development, utilization, management and assessment.

\subsection{Linked Curriculum of Prodi TP with KKNI and Standard AECT 2012}

The development of TP S1 curriculum based on KKNI follow the standard of 6 KKNI namely; 1) Ability to apply the field of expertise and utilize science, technology, and/or art in the field in problem solving and able to adapt to the situation at hand; 2) Mastering the theoretical concepts of a particular field of knowledge in general and the theoretical concepts of a special section in the field of such knowledge in depth, and capable of formulating problem-solving procedural; 3) Be able to make informed decisions based on information and data analysis, and be able to provide guidance on choosing various alternative solutions independently and in groups. 4) Responsible for the work itself and may be given responsibility for the achievement of the work of the organization (appendix KKNI, 2012; 3). Standardization of curriculum development including research process of education technology oriented on improving the 
quality of human resources of Indonesia is an urgent necessity to do (Surahman, 2014).

Setyosari (2016) explains that the application of college KKNI emphasizes that all study programs do the following: 1) to develop a description of learning achievement at least refers to KKNI in the field of higher education according to the level; 2) preparing curriculum, implementing and evaluating curriculum implementation referring to KKNI; 3) develop internal quality assurance system to ensure the achievement of learning achievement of study program.

The process of learning achievement, profile and competence of TP processors ideally also follow international standard compiled by AECT which consists of 5 standards, namely standard 1 on the subject of knowledge, standard 2 on pedagogical materials, standard 3 on the learning environment, standard 4 on knowledge and skills Professional, and standard 5 on research (Standard AECT 2012). Standard AECT 2012 is considered necessary because of the progressive development of Science and Technology, the characteristics of learners are diverse in nature, and the propensity of information dissemination factor and communication process through smart telephon is faster (Surahman \& Surjono, 2017).

Setyosari (2016) describes the relationship between KKNI and AECT 2012 standard in preparing the grain of learning achievement in TP program is as follows:

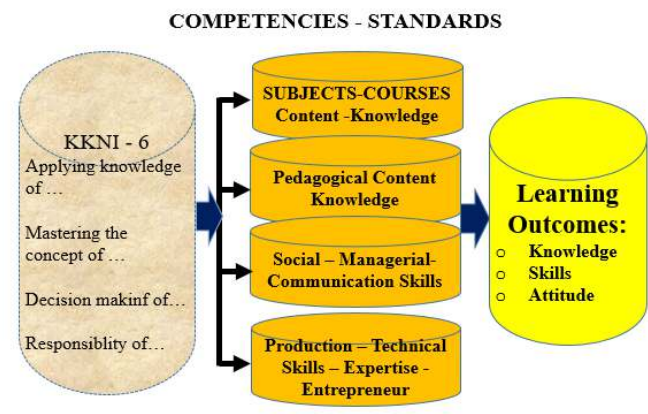

Figure 1. Curriculum Development Standards Prodi TPSource: Setyosari, 2016

\subsection{Links Between Learning Achievements, Graduate Profiles, Standard KKNI Skills Demands And Expertise In Functional Positions Of PTP}

The development of TP S1 curriculum program in Indonesia is required to be consistent with the competence demands in the field, both in government and non-government institutions. Thus the curriculum and learning achievement of graduates of TP S1 program in Indonesia must meet the minimum standards required by the government through the policy of KKNI. In addition, the developed curriculum must also be able to meet the minimum standard of core duty in the functional position of PTP, and adjusted to the development of international TP science compiled by AECT on AECT standard in 2012.

As far as the author's observation, the last few years there have been several efforts towards standardization of TP program curriculum in Indonesia initiated by APS-TPI. In formulating learning achievement based on KKNI and TP science standard according to AECT 2012 standard (Collective Meeting of APS-TPI to-1 in Gorontalo 2015, 2nd in Malang 2016 and 3rd in Banjarmasin, 2017). These efforts show that there is a common perception in the development of scholarship and career of TP graduates from upstream to downstream. It is based on the understanding of all TP Prodi organizers and related organizations such as the Association of Learning Technology Developers (APTPI) and the Indonesian Education Technology Profession Association (IPTPI)

\subsection{Typical Lectures from Prodi S1 TP UM, UPI, UNJ, and UNDIKSHA}

In addition to analyzing the uniformity of subjects taught in the study program S1 S1 UM, UPI, UNJ, and UNDIKSHA, based on the document curriculum analyzed the author, obtained information about subjects typical S1 study program TP. Here are some courses that are typical of each study program.

Typical subjects from the S1 TP S1 program include; Integrated learning, learning characteristics, learning comfort, and basic teaching skills. Typical subjects from S1 TPI UPI such as; Algorithms and programming, software engineering. Typical subjects from S1 S1 program of UNJ are; Learning and performance, performance technology, computer graphics and classroom management. While the typical subjects of S1 TP UNDIKSHA program such as micro learning, reportage, public relations and journalism. Typical course is a course contained in a clump of additional subjects of expertise

\section{CONCLUSIONS RECOMMENDATIONS}

AND

Mapping of learning achievement and profile of TP program graduates in Indonesia generally 
undergoes dynamic changes. This is closely related to the related policy changes such as Presidential Regulation No. 8/2012 on the Indonesian National Qualification Framework (KKNI), then the policy on the Regulation of the State Minister of State Apparatus Empowerment No. 2 Year 2009 on the Position of the Learning Technology Developers Functions and their Credit Numbers. In addition, the internationally developed TP scientific standard developed by AECT is set out in the AECT 2012 standard. All these policy changes are in line with the demands of HR graduates who are expected to compete competitively at national, regional and international levels. The TP program implementers who are members of APS-TPI also make the right step that is to make learning achievement of TPbased graduate of KKNI and the demands of the main task of functional position of learning technology.

Based on the author's analysis, there are several suggestions that need to be revealed to all parties involved in developing the TP's scientific excitement and role in Indonesia, among others; 1) to continue the intensive study of the existence and development of TP science; 2) encouraging the policy of the need for technological developer technology developers in every educational unit (school); 3 ) the need for further formulation of the compulsory subjects (core) of the TP science field in all organizational study programs in Indonesia; and 4) Encourage the uniqueness of additional expertise in each TP study program to enrich the repertoire of TP science in Indonesia.

\section{REFERENCES}

[1] Achievement of Learning Technology S1 APS-TPI 2017. (Online), (http://aps-tpi.org/?page id=2) accessed August 7, 2017

[2] Curriculum Study Program S1 Education Technology State University of Jakarta

[3] Curriculum Study Program S1 Education Technology Department of Educational Technology State University of Malang Year 2015.

[4] Curriculum of Education Technology Education Program Universitas Pendidikan Indonesia 2013. (Online), (http://kurtek.upi.edu/?page_id=18), accessed August 7, 2017

[5] Oka, G., P., A.,. 2012. Learning Technology Profession; Perspective and Opportunity. (Online), (http://lemlit.undiksha.ac.id/media/806.pdf), accessed August 7, 2017

[6] Regulation of the State Minister for the Empowerment of the State Apparatus Number:PER/2/M.PAN/3/2009 concerning the Functional Position of the Developer of Learning Technology and its Credit Score. (Online), (http://bkd.tanahbumbukab.go.id/wpcontent/uploads/2016/10/ PERMENPAN-NOMOR-PER-2-
M.PAN-3-2009@JABATAN-FUNGSIONALDEMBEMBANG-TEMBEMBOLATI -LEDGE-ANDCREDITNYA.pdf), accessed August 7, 2017.

[7] Regulation of the President of the Republic of Indonesia Number 8 Year 2012 on the Indonesian National Qualification Framework. (Online), (http://kknikemenristekdikti.org/asset/pdf/perpres no 8 tahun $2012 \mathrm{tt}$ g_kkni.pdf), accessed August 7, 2017.

[8] Setyosari, P. 2016. Education Technology Program Curriculum. (On line). (Http://aps-tpi.org/?page_id=2), accessed August 7, 2017.

[9] Surahman, E., Alfindasari, D.,. 2014. Sumber Daya dan Pendidikan di Era Global; Sebuah Tinjauan Terhadap Penelitian Teknologi Pendidikan di Indonesia. (Online), (http://www.academia.edu/download/

37322925/SEMNAS - TPPPSUNY - DESSY ENCE PPS_UNY.rtf), accesed August 7, $20 \overline{1} 7$.

[10] Surahman., E. Surjono, H.D. 2017. Pengembangan Adaptive Mobile Learning pada Mata Pelajatan Biologi SMA sebagai Upaya Mendukung Proses Blended Learning. Jurnal Inovasi Teknologi Pendidikan, Volume 4 N0 1 April 2017, 26-37. (Online), (http://journal.uny.ac.id/index.php/ jitp/article/download/9723/9311), Accesed, August 7, 2017.

[11] Curriculum Structure S1 Study Program S1 Education Technology Universitas Ganesha. (Online), (http://tp.undiksha.ac.id/struktur-kurikulum), accessed August 7, 2017. 